\title{
Oil chemical traits of kernels of different almond cultivars from China
}

\author{
Qin WANG ${ }^{1}$, Fenglan $\mathrm{LIU}^{1}$, Jiangfei $\mathrm{MENG}^{2}$, Jinmei MAO${ }^{1}$, Liuping $Z \mathrm{ZANG}^{3}$, Jianyou WANG ${ }^{4}$
}

\begin{abstract}
Traditional cultivars account for a large part of worldwide almond cultivars. However, the oil chemical traits of traditional almond cultivars in China remain unclear. Here, the oil chemical traits of four native and two traditional almond cultivars grown in China were determined. The content of unsaturated and monounsaturated fatty acids ranged from $93.02 \%$ to $93.29 \%$ and $75.24 \%$ to $77.98 \%$, respectively. The tocopherol content varied between 25.15 and $18.37 \mathrm{mg} / 100 \mathrm{~g}$. $\beta$-sitosterol content varied between $93.06 \%$ and $94.40 \% . \mathrm{VB}_{1}, \mathrm{VB}_{2}, \mathrm{VB}_{3}$, and $\mathrm{VB}_{6}$ contents ranged from 0.11 to $0.23,0.26$ to $0.73,370.00$ to 1272.00 , and 0.05 to $0.07 \mathrm{mg} / 100 \mathrm{~g}$, respectively. The levels of squalene and phospholipids ranged from 131.20 to $274.80 \mathrm{mg} / \mathrm{kg}$ and 1.18 to $1.47 \mathrm{mg} / \mathrm{g}$, respectively. These results indicated that the composition and content of fatty acids, tocopherols, sterols, $\mathrm{VB}_{1}$, $\mathrm{VB}_{2}, \mathrm{VB}_{3}, \mathrm{VB}_{6}$, squalene, and phospholipids in almond kernels were significantly different among the investigated cultivars.
\end{abstract}

Keywords: almond; cultivar; fatty acids; tocopherols; sterols.

Practical Application: This study will show the oil chemical traits of kernels from six main almond cultivars in China.

\section{Introduction}

Almonds are one of the most popular edible nuts worldwide. In the global dry fruit market, their annual output is the highest compared to those of hazelnut, walnut, and cashew. Almonds are cholesterol-and gluten-free. They are high in monounsaturated fats, antioxidants, and are a great energy source, which is beneficial for heart health and weight management (Cassady et al., 2009; Abaspour et al., 2012; Maestri et al., 2015; Čolić et al., 2017). They are consumed not only as snack foods, but also used as ingredients in a variety of processed foods and in the pharmaceutical and cosmetic industries (Bolling et al., 2010; Socias i Company et al., 2017).

In China, the almond growing region mainly includes Shache County, Kashgar Prefecture, Xinjiang Uygur Autonomous Region. The region accounts for $95 \%$ of the total Chinese almond output. Many native almond cultivars are grown here, such as 'Zhipi', 'Wanfeng,' 'Xiaoruanke,', 'Shuangruan', and 'Yingzui'. Traditional cultivars, such as 'Nonpareil' and 'Mission', were introduced from California in 1996, and they have been extensively popularised in the Shache region.

To date, the studies on almond cultivars in the Shache region have mainly focused on kernel qualities and amino acid composition. Even though the oil chemical traits of native cultivars have been reported, the chemical content of the oil of traditional cultivars is still unknown. Zhou et al. (2016) studied the characteristics of cold pressed oil extracted from eight almond cultivars in Xinjiang and found that the nutritional value, oxidation stability, and flavour quality of the oil of 'SC-9', 'SC-Zhipi', and 'SC-Taxi' cultivars were better than those of the other five cultivars and that they were suitable for the cold-press process. Yin et al. (2015) determined the physical (shell thickness, kernel percentage, and kernel mass) and chemical qualities (crude fat content, crude protein content, and amygdalin content) of 38 almond cultivars in Xinjiang. They showed that the comprehensive qualities of cultivars, such as 'Zhipi,' 'Butte, 'Thompson, 'Sonora,' 'Nonpareil', 'Ye'erqiang', and 'Badanwang,' were the best among the investigated cultivars. Li et al. (2004) used gas chromatography (GC) to test the contents and composition of fatty acids in 28 almond varieties from Xinjiang. They found that the unsaturated acid content of almond accounted for $92.3 \%$ of the total fatty acid content, and the share of oleic acid ranged from $63.72 \%$ to $75.89 \%$.

Throughout the world, traditional cultivars are the main and most popular cultivars in the almond industry, but the oil chemical traits of traditional almond cultivars in China have not been investigated to date. Therefore, the objective of this study was to determine the oil chemical traits of kernels in typical and traditional native almond cultivars from the Shache region, including the contents of fatty acids, tocopherols, sterols, $\mathrm{B}$ vitamins $\left(\mathrm{VB}_{1}, \mathrm{VB}_{2}, \mathrm{VB}_{3}\right.$, and $\left.\mathrm{VB}_{6}\right)$, squalene, and phospholipids, in order to provide the basis for the production and development of Chinese almond industry.

\section{Materials and methods}

\subsection{Study material}

Raw almonds (six cultivars: 'Zhipi,' 'Shuangruan,' 'Xiaoruanke', 'Wanfeng,' 'Nonpareil', and 'Mission') were collected from the No. 2 state forestry farm of Shache County in 2018. The almond trees in 
the orchard were 16 years old with a spacing of $4 \mathrm{~m} \times 6 \mathrm{~m}$. Shache County has a warm temperate continental arid climate and four distinct seasons. It is dry and rainless, with strong evaporation and abundant sunshine and heat. Sand wind and floating dust are present in spring and less snow falls during winter. The average annual temperature is $11.3^{\circ} \mathrm{C}$, average annual precipitation is $47.6 \mathrm{~mm}$, and annual frost-free period is 220 days.

For each almond cultivar, samples of $3.0 \mathrm{~kg}$ were taken collected the entire canopy of five selected trees. The almonds were hand-harvested at full maturity and dried on the ground with sun exposure until the kernel moisture content reached $5 \%$. The almonds were cracked and shelled manually, and the kernels were ground using a universal cutting mill.

\subsection{Oil analysis}

Oil extraction. The kernels were dried in an oven at $80{ }^{\circ} \mathrm{C}$ until their moisture content was under $10 \%$, and they were then stored in desiccators until further analysis. Oil extraction was carried out according to Sorkheh et al. (2016). The ground kernels were extracted by n-hexane in a Soxhlet apparatus. The extracted oil bottled in flasks was dried under vacuum conditions in an oven at $80^{\circ} \mathrm{C}$ for $30 \mathrm{~min}$ and cooled in a dryer.

Fatty acid composition. Fatty acid composition was analysed by the normalisation method according to Zhou et al. (2016). A total of $20.0 \mathrm{mg}$ of oil, $2.5 \mathrm{~mL}$ of $\mathrm{n}$-hexane, and $100.0 \mu \mathrm{L}$ of $0.5 \mathrm{~mol} / \mathrm{L}$ sodium methoxide were added to a $10 \mathrm{~mL}$ centrifuge tube. The solution was mixed for $5 \mathrm{~min}$ and then centrifuged at $5000 \mathrm{rpm}$ for $10 \mathrm{~min}$. The supernatant was used for analysing the fatty acid profile using an Agilent 7890A gas chromatograph (Agilent Corporation, Santa Clara, CA, USA). The GC conditions were as follows: the chromatographic column was the Agilent HP-INNOWAX $(30 \mathrm{~m} \times 0.32 \mathrm{~mm} \times 0.25 \mathrm{~m})$; nitrogen was the carrier gas; flow rate was $1.5 \mathrm{~mL} / \mathrm{min}$; inlet temperature was $260^{\circ} \mathrm{C}$; split ratio was $80: 1$. After keeping the solution at $210^{\circ} \mathrm{C}$ for $9 \mathrm{~min}$, the temperature was increased to $250{ }^{\circ} \mathrm{C}$ at a rate of $20^{\circ} \mathrm{C} / \mathrm{min}$, and the solution was kept at $250^{\circ} \mathrm{C}$ for $10 \mathrm{~min}$. The injection volume was $1.0 \mu \mathrm{L}$. The area normalisation method was used to quantitatively determine the percentage of fatty acids.

Tocopherol composition. Tocopherol content was determined by reversed-phase high performance liquid chromatography (RP-HPLC) according to Al Juhaimi et al. (2018). After oscillating $5.0 \mathrm{~g}$ of ground kernels and $0.5 \mathrm{~g}$ of amylase in a $60{ }^{\circ} \mathrm{C}$ water bath without sunshine for $30 \mathrm{~min}$, they were mixed with $1.0 \mathrm{~g}$ of ascorbic acid, $0.1 \mathrm{~g}$ of BHT, $30.0 \mathrm{~mL}$ of anhydrous ethanol, and $10.0 \mathrm{~mL}$ of $5.0 \mathrm{~g} / \mathrm{ml}$ potassium hydroxide solution. The mixture was saponified in a water bath at $80{ }^{\circ} \mathrm{C}$ and oscillated for $30 \mathrm{~min}$. A total of $50.0 \mathrm{~mL}$ of petroleum ether-ethyl ether mixture $(1: 1 \mathrm{v} / \mathrm{v})$ was added into the extracted saponification liquid. After cleaning the ether layer with $100.0 \mathrm{~mL}$ of water, it was concentrated with $3.0 \mathrm{~g}$ of anhydrous sodium sulphate and $15.0 \mathrm{~mL}$ of petroleum ether in a Senco R-501 rotary evaporator (Shanghai Shensheng Biotech Co. Ltd., Shanghai, China). Then, the concentration was stabilised by methanol to $10.0 \mathrm{~mL}$. The tocopherol profile was analysed using an Agilent 1100 liquid chromatograph (Agilent Corporation, Santa Clara, CA, USA). The HPLC conditions were as follows: the chromatographic column was a C18 Kromasil column $(5 \mu \mathrm{m} \times 4.6 \mathrm{~mm} \times 250 \mathrm{~m})$; column temperature was $20^{\circ} \mathrm{C}$; mobile phase was $\mathrm{A}$ (water) and $\mathrm{B}$ (methanol). The gradient elution conditions were as follows: 0-13 min, 96\%-96\% B; 13-20 min, 96\%-100\% B; 20-24 min, $100 \%-100 \% \mathrm{~B} ; 24-24.5 \mathrm{~min}, 100 \%-96 \% \mathrm{~B} ; 24.5-30 \mathrm{~min}$, $100 \%-96 \% \mathrm{~B}$. The flow rate was $0.8 \mathrm{~mL} / \mathrm{min}$, UV detection wavelength was $294 \mathrm{~nm}$, and injection volume was $10 \mu \mathrm{L}$. The retention time was used for qualitative analysis, and the internal standard method was used for quantitative analysis.

Sterol composition. Sterol was extracted by GC according to the method described in Amaral et al. (2003). A total of $250.0 \mathrm{mg}$ of extracted oil was saponified with $1.0 \mathrm{~mL}$ of $1.0 \mathrm{mg} / \mathrm{mL}$ acetone and $5.0 \mathrm{~mL}$ of $0.5 \mathrm{~mol} / \mathrm{L}$ ethanolic potassium hydroxide solution for $15 \mathrm{~min}$. After heating, $5 \mathrm{~mL}$ of ethanol was added to the mixture while the mixture was hot. An aluminium oxide column was used to isolate the unsaponifiable fraction by solid-phase extraction. The unsaponifiable fraction was extracted with $5.0 \mathrm{~mL}$ of ethanol and $30.0 \mathrm{~mL}$ of diethyl ether, and then dissolved in diethyl ether by thin-layer chromatography. Methanol was sprayed to visualise the band. After scraping off the silicone layer with a blade and adding $0.5 \mathrm{~mL}$ of ethanol, the solution was concentrated. After adding $100.0 \mu \mathrm{L}$ of silyl reagents into the reaction flask, the flask was sealed and placed in an oven at $105^{\circ} \mathrm{C}$ for $15 \mathrm{~min}$. The sterol profile was analysed using an Agilent 7890A gas chromatograph (Agilent Corporation, Santa Clara, CA, USA). The GC conditions were as follows: chromatographic column was an Agilent HP-5 column $(0.25 \mu \mathrm{m} \times 0.320 \mathrm{~mm} \times 30 \mathrm{~m})$; hydrogen was the carrier gas; flow rate was $36 \mathrm{~cm} / \mathrm{s}$; split ratio was 1:20; injector and detector temperatures were both $320^{\circ} \mathrm{C}$. The column temperature was increased from $240{ }^{\circ} \mathrm{C}$ to $255^{\circ} \mathrm{C}$ at a rate of $4{ }^{\circ} \mathrm{C} / \mathrm{min}$. The injection volume was $1.0 \mu \mathrm{L}$. The retention time was used for qualitative analysis, and the internal standard method was used for quantitative analysis.

$B$ vitamin contents. $B$ vitamins $\left(\mathrm{VB}_{1}, \mathrm{VB}_{2}, \mathrm{VB}_{3}\right.$, and $\left.\mathrm{VB}_{6}\right)$ were evaluated by HPLC according to Köksal et al. (2006).

VB $_{1}$ content. Ground kernels $(0.5 \mathrm{~g})$ were weighed in a $100 \mathrm{~mL}$ centrifuge tube. After adding $50.0 \mathrm{~mL}$ of $0.5 \mathrm{~mol} / \mathrm{L}$ hydrochloric acid solution, the mixture was ultrasonically extracted in an $80^{\circ} \mathrm{C}$ water bath for $30 \mathrm{~min}$. Then, the solution was centrifuged at $4000 \mathrm{rpm}$ for $10 \mathrm{~min}$. The supernatant was used for $\mathrm{VB}_{1}$ content analysis. $\mathrm{VB}_{1}$ content was analysed using an Agilent 1100 liquid chromatograph (Agilent Corporation, Santa Clara, CA, USA). The HPLC conditions were as follows: the chromatographic column was a C18 Kromasil column $(5 \mu \mathrm{m} \times 4.6 \mathrm{~mm} \times 250 \mathrm{~m})$; column temperature was $30^{\circ} \mathrm{C}$; mobile phase was A (acetonitrile) and B (0.1\% trifluoroacetic acid solution). The gradient elution conditions were as follows: 0-0.7 $\mathrm{min}, 100 \%-100 \% \mathrm{~B}$; 0.7-5 $\mathrm{min}, 100 \%-97 \% \mathrm{~B}$; 5-6 min, 97\%-85\% B; 6-11 $\mathrm{min}, 85 \%-80 \% \mathrm{~B}$; $11-11.5 \mathrm{~min}, 80 \%-10 \%$ B; $11.5-15.5 \mathrm{~min}, 10 \%-10 \% \mathrm{~B}$; $15.5-16 \mathrm{~min}, 10 \%-100 \% \mathrm{~B}$; $16-20 \mathrm{~min}, 100 \%-100 \% \mathrm{~B}$. The flow rate was $1.3 \mathrm{~mL} / \mathrm{min}, \mathrm{UV}$ detection wavelength was $280 \mathrm{~nm}$, and injection volume was $10 \mu \mathrm{L}$. The retention time was used for qualitative analysis, and the internal standard method was used for quantitative analysis.

$\mathrm{VB}_{2}$ content. A total of $10.0 \mathrm{~g}$ of ground kernels was weighed in a $100 \mathrm{~mL}$ centrifuge tube. After adding $60.0 \mathrm{~mL}$ of $0.1 \mathrm{~mol} / \mathrm{L}$ hydrochloric acid solution, the mixture was kept in a highhanded sterilisation pan at $121^{\circ} \mathrm{C}$ for $30 \mathrm{~min}$. After adjusting 
the $\mathrm{pH}$ value to 6.0 by $1 \mathrm{~mol} / \mathrm{L}$ sodium hydroxide solution, the mixture was added $2.0 \mathrm{~mL}$ of mixed enzyme solution, and it was enzymed in an incubator at $37^{\circ} \mathrm{C}$. The volume of the enzymed liquid was adjusted to $100.0 \mathrm{~mL}$ and filtered. The supernatant was used for $\mathrm{VB}_{2}$ content analysis. $\mathrm{VB}_{2}$ was analysed using an Agilent 1100 liquid chromatograph (Agilent Corporation, Santa Clara, CA, USA). The HPLC conditions were as follows: the chromatographic column was a C18 Kromasil column $(5 \mu \mathrm{m} \times 4.6 \mathrm{~mm} \times 250 \mathrm{~m})$; column temperature was $30{ }^{\circ} \mathrm{C}$; mobile phase was $0.05 \mathrm{~mol} / \mathrm{L}$ sodium acetate solution $65 \%$ $(\mathrm{v} / \mathrm{v})$ containing methanol $35 \%(\mathrm{v} / \mathrm{v})$; flow rate was $1 \mathrm{~mL} / \mathrm{min}$; excitation wavelength was $462 \mathrm{~nm}$; emission wavelength was $522 \mathrm{~nm}$; injection volume was $20 \mu \mathrm{L}$. The retention time was used for qualitative analysis, and the internal standard method was used for quantitative analysis.

$\mathrm{VB}_{3}$ content. After mixing $5.0 \mathrm{~g}$ of ground kernels and $25.0 \mathrm{~mL}$ of $45-50{ }^{\circ} \mathrm{C}$ water, $20.0 \mathrm{~g}$ of samples and $0.50 \mathrm{~g}$ of amylase were added to a $150 \mathrm{~mL}$ conical flask. The mixture was charged with nitrogen, covered with a plug, and then cultured in a $50-60{ }^{\circ} \mathrm{C}$ incubator for $30 \mathrm{~min}$. A total of $5.0 \mathrm{~mol} / \mathrm{L}$ of hydrochloric acid solution and $0.1 \mathrm{~mol} / \mathrm{L}$ of hydrochloric acid solution were used to adjust the $\mathrm{pH}$ value of the sample solution to 4.5. Then, the sample was placed in a bath ultrasonic oscillator at $50{ }^{\circ} \mathrm{C}$ water and oscillated for $10 \mathrm{~min}$. The volume of the solution was adjusted to $100 \mathrm{~mL}$, and the solution was then filtered. The supernatant was used for $\mathrm{VB}_{3}$ content analysis. $\mathrm{VB}_{3}$ was analysed with a Waters 2695 liquid chromatograph (Waters Corporation, Milford, CT, USA). The HPLC conditions were as follows: the chromatographic column was a C18 Kromasil column $(5 \mu \mathrm{m} \times 4.6 \mathrm{~mm} \times 250 \mathrm{~m})$; column temperature was $25^{\circ} \mathrm{C}$; mobile phase was as follows: $70.0 \mathrm{~mL}$ of methanol, $20.0 \mathrm{~mL}$ of isopropanol, and $1.0 \mathrm{~g}$ of sodium 1-heptanesulfonate heptane sulphonate dissolved in $910.0 \mathrm{~mL}$ of water. Perchloric acid was used to adjust the $\mathrm{pH}$ value to 2.1 , and the sample liquid was then filtered through a $0.45 \mu \mathrm{m}$ membrane. The flow rate was $1.0 \mathrm{~mL} / \mathrm{min}$, UV detection wavelength was $261 \mathrm{~nm}$, and injection volume was $10 \mu \mathrm{L}$. The retention time was used for qualitative analysis, and the internal standard method was used for quantitative analysis.

$\mathrm{VB}_{6}$ content. A total of $5.0 \mathrm{~g}$ of grounded kernels, $25.0 \mathrm{~mL}$ of $45-50^{\circ} \mathrm{C}$ water, and $0.5 \mathrm{~g}$ of amylase were added to a $150 \mathrm{~mL}$ conical flask. The mixture was charged with nitrogen, covered with a plug, and then cultured in a $50-60{ }^{\circ} \mathrm{C}$ incubator for about $30 \mathrm{~min}$. A total of $5.0 \mathrm{~mol} / \mathrm{L}$ of hydrochloric acid solution was used to adjust the $\mathrm{pH}$ value of the sample solution to 1.7. The sample was incubated for $1 \mathrm{~min}$. A total of $5.0 \mathrm{~mol} / \mathrm{L}$ sodium hydroxide solution was used to adjust the $\mathrm{pH}$ value of the sample solution to 4.5. After ultrasonic oscillation for $10 \mathrm{~min}$, the volume of the solution was adjusted to $50.0 \mathrm{~mL}$, and the solution was filtered. The supernatant was used for $\mathrm{VB}_{6}$ content analysis. $\mathrm{VB}_{6}$ was analysed using an Agilent 1100 liquid chromatograph (Agilent Corporation, Santa Clara, CA, USA). The HPLC conditions were as follows: the chromatographic column was a C18 Kromasil column $(5 \mu \mathrm{m} \times 4.6 \mathrm{~mm} \times 250 \mathrm{~m})$; column temperature was $30{ }^{\circ} \mathrm{C}$; mobile phase was as follows: $50.0 \mathrm{~mL}$ of methanol, $2.0 \mathrm{~g}$ of sodium 1-octanesulfonate, and $2.5 \mathrm{~mL}$ of triethylamine were dissolved and adjusted to $1000 \mathrm{~mL}$ by water. Glacial acetic acid was used to adjust the $\mathrm{pH}$ value to 3.0 . Then, the sample liquid was filtered through a $0.45 \mu \mathrm{m}$ membrane. The flow rate was $1.0 \mathrm{~mL} / \mathrm{min}$, excitation wavelength was $293 \mathrm{~nm}$, emission wavelength was $395 \mathrm{~nm}$, and injection volume was $10 \mu \mathrm{L}$. The retention time was used for qualitative analysis, and the internal standard method was used for quantitative analysis.

Squalene content. Squalene was detected using the GC method as described in Maguire et al. (2004). Extracted oil $0.2 \mathrm{~g}$ and $50.0 \mathrm{~mL}$ of $1 \mathrm{~mol} / \mathrm{L}$ potassium hydroxide-ethanol solution were saponified (reflux in a water bath pot at $80^{\circ} \mathrm{C}$ for $50 \mathrm{~min}$ ), after which $50.0 \mathrm{~mL}$ of water was added. The saponification liquid was extracted with $100.0 \mathrm{~mL}$ of $\mathrm{n}$-hexane by separating the funnel. The extraction liquid was cleaned with $25 \mathrm{~mL}$ of $10 \%$ ethanol solution until the $\mathrm{pH}$ value of the lower effluent was 7.0. Then, it was filtered through a filter paper laying $5.0 \mathrm{~g}$ of anhydrous sodium sulphate, concentrated with $20.0 \mathrm{~mL}$ of $\mathrm{n}$-hexane by rotation in a water bath at $40^{\circ} \mathrm{C}$. When there was about $2.0 \mathrm{~mL}$ of $\mathrm{n}$-hexane left in the bottle, the evaporation bottle was removed and immediately put into a pressure blowing concentrator to dry. Then the volume of the solution was adjusted to $10.0 \mathrm{~mL}$ by $\mathrm{n}$-hexane. The squalene content was analysed using an Agilent 7890A gas chromatograph (Agilent Corporation, Santa Clara, CA, USA). The conditions of the GS were as follows: the chromatographic column was an Agilent HP-5 column $(0.25 \mu \mathrm{m} \times 0.320 \mathrm{~mm} \times 30 \mathrm{~m})$; nitrogen was the carrier gas; inlet temperature was $250^{\circ} \mathrm{C}$, split ratio was 1:10. First, the temperature was raised from $160{ }^{\circ} \mathrm{C}$ to $220^{\circ} \mathrm{C}$ at a rate of $15^{\circ} \mathrm{C} / \mathrm{min}$, and the solution was kept at $220^{\circ} \mathrm{C}$ for $2 \mathrm{~min}$. Second, the temperature was increased to $280{ }^{\circ} \mathrm{C}$ at a rate of $5{ }^{\circ} \mathrm{C} / \mathrm{min}$, and the solution was kept at $280^{\circ} \mathrm{C}$ for $2 \mathrm{~min}$. Finally, the temperature was increased to $300{ }^{\circ} \mathrm{C}$ at a rate of $40^{\circ} \mathrm{C} / \mathrm{min}$ and the solution was kept at $300^{\circ} \mathrm{C}$ for $2 \mathrm{~min}$. The flame ionization detector (FID) temperature of the detector was $300^{\circ} \mathrm{C}$, its hydrogen flow rate was $40 \mathrm{~mL} / \mathrm{min}$, air flow rate was $450 \mathrm{~mL} / \mathrm{min}$, and tail gas flow rate was $30 \mathrm{~mL} / \mathrm{min}$. The injection volume was $1.0 \mu \mathrm{L}$. The percentage of fatty acids was quantitatively determined by the area normalisation method.

Phospholipid content. Phospholipid content was determined by the molybdenum blue method according to Jiang et al. (2015).

Extracted oil $3.0 \mathrm{~g}$ and $0.5 \mathrm{~g}$ of zinc oxide were gradually heated until all the mixture carbonised in the crucible. The crucible was burned in a muffle furnace at $550-600{ }^{\circ} \mathrm{C}$ for $2 \mathrm{~h}$ until the mixture was completely ashed. The ash was dissolved with $10.0 \mathrm{~mL}$ of $1.19 \mathrm{~g} / \mathrm{mL}$ salt acid solution, heated to slightly boiling temperature for $5 \mathrm{~min}$, and filtered using $15.0 \mathrm{~mL}$ of hot water. Then, it was neutralised by $50 \%$ potassium hydroxide solution until it gained a muddy appearance. The zinc oxide precipitate was dissolved in a hydrochloric acid solution $(1: 1 \mathrm{v} / \mathrm{v})$, and the volume was adjusted to $100.0 \mathrm{~mL}$ using water. A total of $10.0 \mathrm{~mL}$ of the measured liquid was absorbed with pipette and injected into a $50 \mathrm{~mL}$ colorimetric tube. After mixing $8.0 \mathrm{~mL}$ of $0.015 \%$ hydrazine sulphate solution and $2.0 \mathrm{~mL}$ of $2.5 \%$ sodium molybdate solution, the colourimetric tube was heated in a boiling water bath for $10 \mathrm{~min}$. The tube was diluted with water to scale, shaken well, and allowed to rest for $10 \mathrm{~min}$. Then, the solution was moved to a dry and clean cuvette, and its absorbance was determined by dividing the photometer at $650 \mathrm{~nm}$. 


\subsection{Statistical analysis}

Each test index was repeated three times. The data were analysed using SPSS version 16.0 for Windows (SPSS Inc., USA). One-way analysis of variance (ANOVA) and Duncan's multiple range tests were used to determine the significance of the differences among samples at $\mathrm{p}<0.05$. The results are reported as mean $\pm \mathrm{SD}$ of triplicate experiments. Principal component analysis (PCA) was used to evaluate the relationship between the almond cultivars and oil chemical traits.

\section{Results and discussion}

\subsection{Fatty acid composition}

Fatty acid composition of the investigated almond cultivars is summarised in Table 1. Oleic $\left(\mathrm{C}_{18: 1}\right)$, linoleic $\left(\mathrm{C}_{18: 2}\right)$, and palmitic acid $\left(\mathrm{C}_{16: 0}\right)$ were the three main constitutive fatty acids in all samples. The ranges for these three fatty acids were $74.60 \%$ to $77.30 \%, 15.20 \%$ to $17.90 \%$, and $5.59 \%$ to $5.90 \%$, respectively. These results were consistent with those of a previous study showing that all almond cultivars contained five fatty acids, including oleic $\left(\mathrm{C}_{18: 1}\right)$, linoleic $\left(\mathrm{C}_{18: 2}\right)$, palmitic $\left(\mathrm{C}_{16: 0}\right)$, stearic $\left(\mathrm{C}_{18: 0}\right)$, and palmitoleic acid $\left(\mathrm{C}_{16: 1}\right)$ (Sathe et al., 2008). In the present study, each cultivar had different types of fatty acids. 'Shuangruan' contained the highest number of fatty acids (11), and it was also the only cultivar that contained linolenic acid $\left(\mathrm{C}_{18: 2}\right)$. 'Zhipi' contained the lowest number of fatty acids (5).

The composition of saturated fatty acids (SFA) and unsaturated fatty acids (UFA) in the investigated almond cultivars is summarised in Figure 1. The SFA content ranged from 6.64\% to $7.02 \%$. The main contributing SFA in all cultivars were stearic $\left(\mathrm{C}_{18: 0}\right)$ and palmitic acid $\left(\mathrm{C}_{16: 0}\right)$. 'Shuangruan' and 'Xiaoruanke' had three other SFAs, including myristic $\left(\mathrm{C}_{14: 0}\right)$, heptadecanoic $\left(\mathrm{C}_{17.0}\right)$, and arachidic acid $\left(\mathrm{C}_{20.0}\right)$. The lowest and highest levels of SAF were found in 'Xiaoruanke' and 'Shuangruan', respectively.

The UFA content ranged from $93.02 \%$ to $93.29 \%$. Oleic $\left(C_{18: 1}\right)$ and linoleic acid $\left(\mathrm{C}_{18: 2}\right)$ were the main constituents of the UFA. Compared with that of walnut and hazelnut, the content of UFA in almonds was found to be higher (Ostrowska-Ligeza et al., 2010). The UFA have a variety of physiological functions, such as regulating blood glucose and blood fat and reducing cholesterol content. The content of monounsaturated fatty acids (MUFAs) accounted for $75.24 \%$ to $77.98 \%$ of total fatty acid content. In all cultivars, oleic acid $\left(\mathrm{C}_{18: 1}\right)$ was the dominant MUFA, accounting for over $74.6 \%$ of total fatty acid content. 'Xiaoruanke' had the highest oleic acid $\left(\mathrm{C}_{18: 1}\right)$ content, accounting for $77.3 \%$ of total fatty acid content. In all cultivars, the polyunsaturated fatty acid (PUFA) content ranged from $15.23 \%$ to $17.90 \%$. Only 'Shuangruan' cultivar contained linolenic acid $\left(\mathrm{C}_{18: 2}\right)$ which accounted for $0.03 \%$ of total fatty acid content. Linolenic acid $\left(\mathrm{C}_{18: 2}\right)$ is beneficial for brain development, and it can be converted into docosahexaenoic acid (DHA) by various enzymatic reactions in the human body. The main PUFA present in all six almond cultivars was linoleic acid $\left(\mathrm{C}_{18: 2}\right)$.

The unsaturated/saturated fatty acids ratio of the investigated almond cultivars ranged from $13.26 \%$ to $14.05 \%$, and this ratio was the highest in 'Xiaoruanke' cultivar. Compared to those in walnuts, MUFA content in almonds was 3.52 times higher, whereas PUFA content in almonds was 0.22 times higher (Maguire et al., 2004). Almonds have longer shelf life than walnuts.

\subsection{Tocopherol content}

Tocopherol content of the investigated almond cultivars is shown in Table 2. Tocopherol can prevent the production of peroxides, premature cell ageing, and coronary heart disease (López-Ortiz et al., 2008; Zhu et al., 2015). It is the most important antioxidant in the human body. From highest to lowest, the tocopherol content in the six cultivars was 'Wanfeng', 'Shuangruan', 'Nonpareil', 'Xiaoruanke,' 'Zhipi', and 'Mission', and this content ranged from 25.15 to $18.37 \mathrm{mg} / 100 \mathrm{~g}$. Tocopherol content differed among cultivars. There were four types of tocopherols in the samples. $\alpha$-tocopherol was the predominant form of tocopherol, ranging between $85.16 \%$ and $90.91 \%$, followed by $\gamma$-tocopherol, $\beta$-tocopherol, and $\delta$-tocopherol. Previous studies have reported that $\gamma$-tocopherol is a more potent antioxidant than other tocopherols (Wang et al., 2019). 'Wanfeng' had the highest levels of total tocopherol, $\alpha$-tocopherol, $\beta$-tocopherol, and $\gamma$-tocopherol, whereas 'Mission' had the lowest. The tocopherol content in almonds was 7.50-10.27 times higher than that of walnuts, 5.22-7.14 times higher than that of pistachios, and 33.71-46.15 times higher than that of cashews (Al Juhaimi et al., 2018). Almond cultivars from the Shache region were rich in tocopherol.

Table 1. Fatty acid contents in kernels of six almond cultivars (\%).

\begin{tabular}{|c|c|c|c|c|c|c|}
\hline Fatty acids & 'Zhipi' & 'Shuangruan' & 'Xiaoruanke' & 'Wanfeng' & 'Nonpareil' & 'Mission' \\
\hline $\mathrm{C}_{14: 0}$ & - & $0.03 \pm 0 \mathrm{~b}$ & $0.036 \pm 0 \mathrm{a}$ & - & - & - \\
\hline $\mathrm{C}_{16: 0}$ & $5.67 \pm 0.24 b$ & $5.89 \pm 0.09 a$ & $5.59 \pm 0.04 b$ & $5.90 \pm 0.02 \mathrm{a}$ & $5.76 \pm 0.08 \mathrm{ab}$ & $5.72 \pm 0.06 \mathrm{ab}$ \\
\hline $\mathrm{C}_{16: 1}$ & $0.41 \pm 0.01 \mathrm{c}$ & $0.60 \pm 0.03 a$ & $0.49 \pm 0.01 b$ & $0.58 \pm 0.01 \mathrm{a}$ & $0.48 \pm 0.02 b$ & $0.47 \pm 0 \mathrm{~b}$ \\
\hline $\mathrm{C}_{17: 0}$ & - & $0.05 \pm 0 \mathrm{a}$ & $0.04 \pm 0 \mathrm{a}$ & - & - & - \\
\hline $\mathrm{C}_{17: 1}$ & - & $0.12 \pm 0 \mathrm{~b}$ & $0.13 \pm 0 b$ & $0.11 \pm 0 \mathrm{~d}$ & $0.12 \pm 0 c$ & $0.13 \pm 0 \mathrm{a}$ \\
\hline $\mathrm{C}_{18: 0}$ & $1.18 \pm 0.03 \mathrm{a}$ & $0.10 \pm 0.01 \mathrm{c}$ & $0.90 \pm 0.01 \mathrm{~d}$ & $0.89 \pm 0.01 \mathrm{~d}$ & $1.16 \pm 0.01 \mathrm{a}$ & $1.13 \pm 0.01 b$ \\
\hline $\mathrm{C}_{18: 1}$ & $76.90 \pm 0.26 b$ & $77.00 \pm 0.11 b$ & $77.30 \pm 0.04 a$ & $75.50 \pm 0.04 \mathrm{c}$ & $74.60 \pm 0.05 \mathrm{~d}$ & $76.90 \pm 0.05 b$ \\
\hline $\mathrm{C}_{18: 2}$ & $15.90 \pm 0.04 \mathrm{c}$ & $15.20 \pm 0.06 f$ & $15.30 \pm 0.01 \mathrm{e}$ & $17.10 \pm 0.02 b$ & $17.90 \pm 0.05 a$ & $15.70 \pm 0.01 \mathrm{~d}$ \\
\hline $\mathrm{C}_{18: 3}$ & - & $0.03 \pm 0$ & - & - & - & - \\
\hline $\mathrm{C}_{20: 0}$ & - & $0.06 \pm 0 \mathrm{a}$ & $0.06 \pm 0 \mathrm{a}$ & - & - & - \\
\hline $\mathrm{C}_{20: 1}$ & - & $0.07 \pm 0 \mathrm{a}$ & $0.06 \pm 0 \mathrm{a}$ & - & $0.05 \pm 0 b$ & - \\
\hline
\end{tabular}

Values are mean \pm S.D. Different letters in each row indicate significant differences at the 0.05 confidence levelaccording to ANOVA by Duncan's test. -, not analysed. 

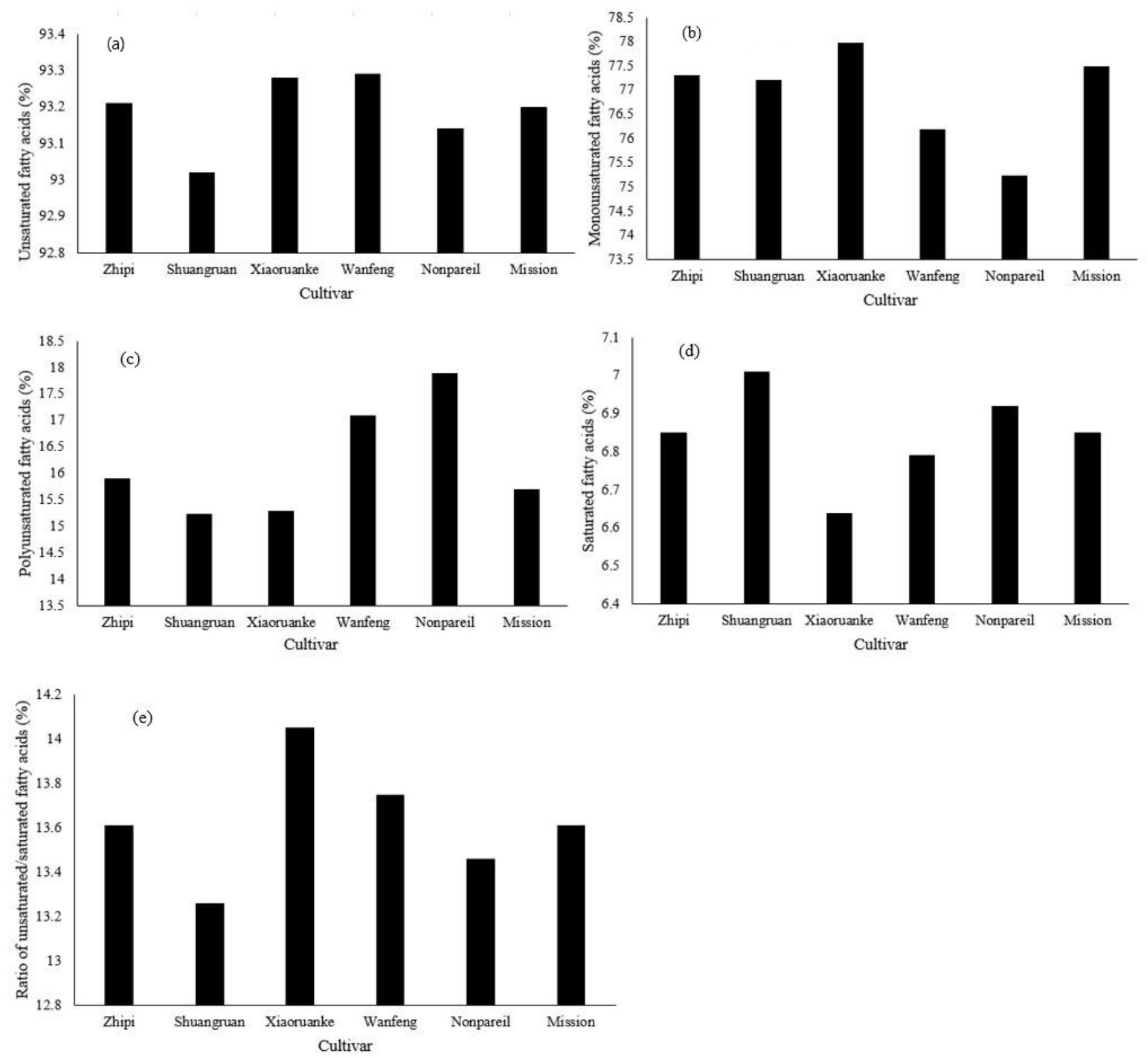

Figure 1. The contents of unsaturated fatty acids (a), monounsaturated fatty acids (b), polyunsaturated fatty acids (c), saturated fatty acids (d), and the ratio of unsaturated/saturated fatty acids (e) in kernels of six almond cultivars.

Table 2. Tocopherol and sterol contents in kernels of six almond cultivars (mg/100 g).

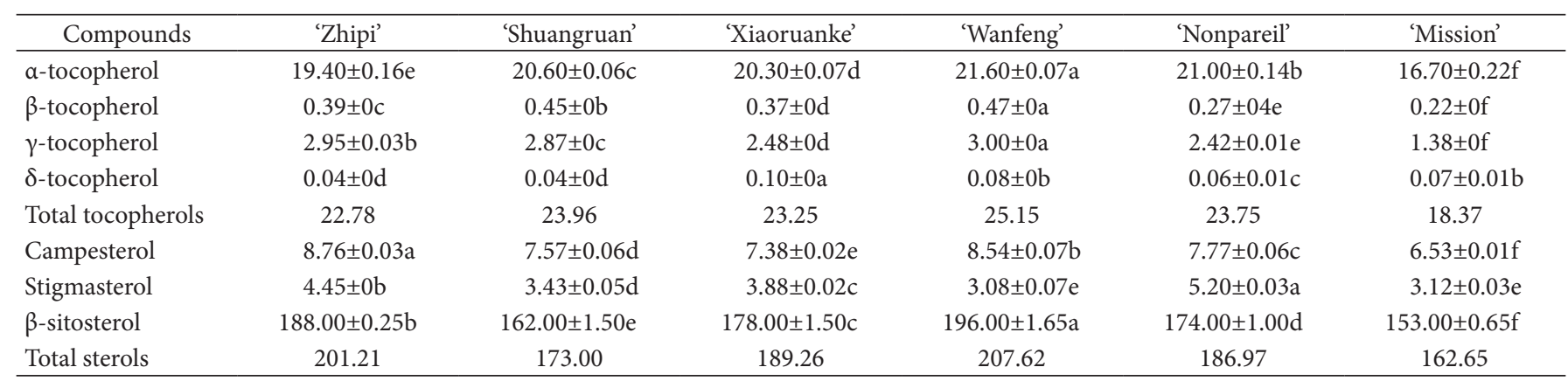

Values are mean \pm S.D. Different letters in each row indicate significant differences at the 0.05 confidence level according to ANOVA by Duncan's test. 


\subsection{Sterol content}

Sterol content in the investigated almond cultivars is shown in Table 2. Sterol can significantly reduce the content of triacylglycerin and cholesterol in the plasma, decrease the content of plasma low-density lipoprotein, and inhibit the activity of cancer cells (Derewiaka \& Obiedziński, 2012; Lehtonen et al., 2012; Vanmierlo et al., 2013). There were three types of sterols in the samples, and their percentage distributions varied among the cultivars. $\beta$-sitosterol is the dominant sterol, ranging between $93.06 \%$ and $94.40 \%$. Campesterol and stigmasterol varied between $6.53-8.76 \mathrm{mg} / 100 \mathrm{~g}$ and $3.12-5.20 \mathrm{mg} / 100 \mathrm{~g}$, respectively. From highest to lowest, total sterol contents in the six cultivars were: 'Wanfeng', 'Zhipi', 'Xiaoruanke, 'Nonpareil', 'Shuangruan', and 'Mission'. Sterol content in 'Wanfeng' was 1.28 times higher than that in 'Mission'. Sterol content in almonds was higher than that found in walnuts, macadamia nuts, and hazelnuts (Maguire et al., 2004).

\subsection{Content of $B$ vitamins}

$B$ vitamins are essential nutrients for the maintenance of life as they play an important role in metabolism (Hälvin et al., 2014; Hu et al., 2018). They cannot be synthesised in bodies and must be obtained from the outside.

$\mathrm{VB}_{1}$, called thiamine, is a coenzyme of thiamine pyrophosphate (TPP) (Settembre et al., 2003; Fitzpatrick \& Thore, 2014). In the present study, 'Xiaoruanke' had the highest $\mathrm{VB}_{1}$ level of $0.23 \mathrm{mg} / 100 \mathrm{~g}$, and 'Mission' had the lowest $\mathrm{VB}_{1}$ level of $0.11 \mathrm{mg} / 100 \mathrm{~g}$ (Figure 2).

$\mathrm{VB}_{2}$, called riboflavin, is present in the form of flavin mononucleotide (FMN) and flavin adenine dinucleotide (FAD) in different organisms (Schwechheimer et al., 2016). It is a coenzyme of some oxidoreductases, taking part in many redox reactions. In the present study, the content of $\mathrm{VB}_{2}$ among the cultivars ranged from 0.26 to $0.73 \mathrm{mg} / 100 \mathrm{~g}$. The highest $\mathrm{VB}_{2}$ content in the cultivar 'Mission' was 2.78 times higher than that in 'Wanfeng', which had the lowest $\mathrm{VB}_{2}$ content.

$\mathrm{VB}_{3}$, called nicotinic acid, is the precursor of nicotinamide adenine dinucleotide (NAD+, coenzyme I) and nicotinamide adenine dinucleotide phosphoric acid (NADP+, coenzyme II) in different organisms. It is involved in various enzymatic redox reactions. From highest to lowest, $\mathrm{VB}_{3}$ content was as follows: Nonpareil'> 'Zhipi'> 'Shuangruan'> 'Xiaoruanke'> 'Mission'> 'Wanfeng. The highest $\mathrm{VB}_{3}$ content was observed in 'Nonpareil' (1272 mg/100 g), whereas the lowest was observed in 'Wanfeng' (639 mg/100 g).

$\mathrm{VB}_{6}$, called pyridoxine, exists as phosphate in living organisms. It is the main coenzyme of various enzymes involved in amino acid and fatty acid metabolism (Clase et al., 2013; Fitzpatrick \& Thore, 2014). The content of $\mathrm{VB}_{6}$ in 'Xiaoruanke' was the highest among the six cultivars $(0.07 \mathrm{mg} / 100 \mathrm{~g})$, and it was 1.49 times higher than that of 'Zhipi', which had the lowest $\mathrm{VB}_{6}$ content.
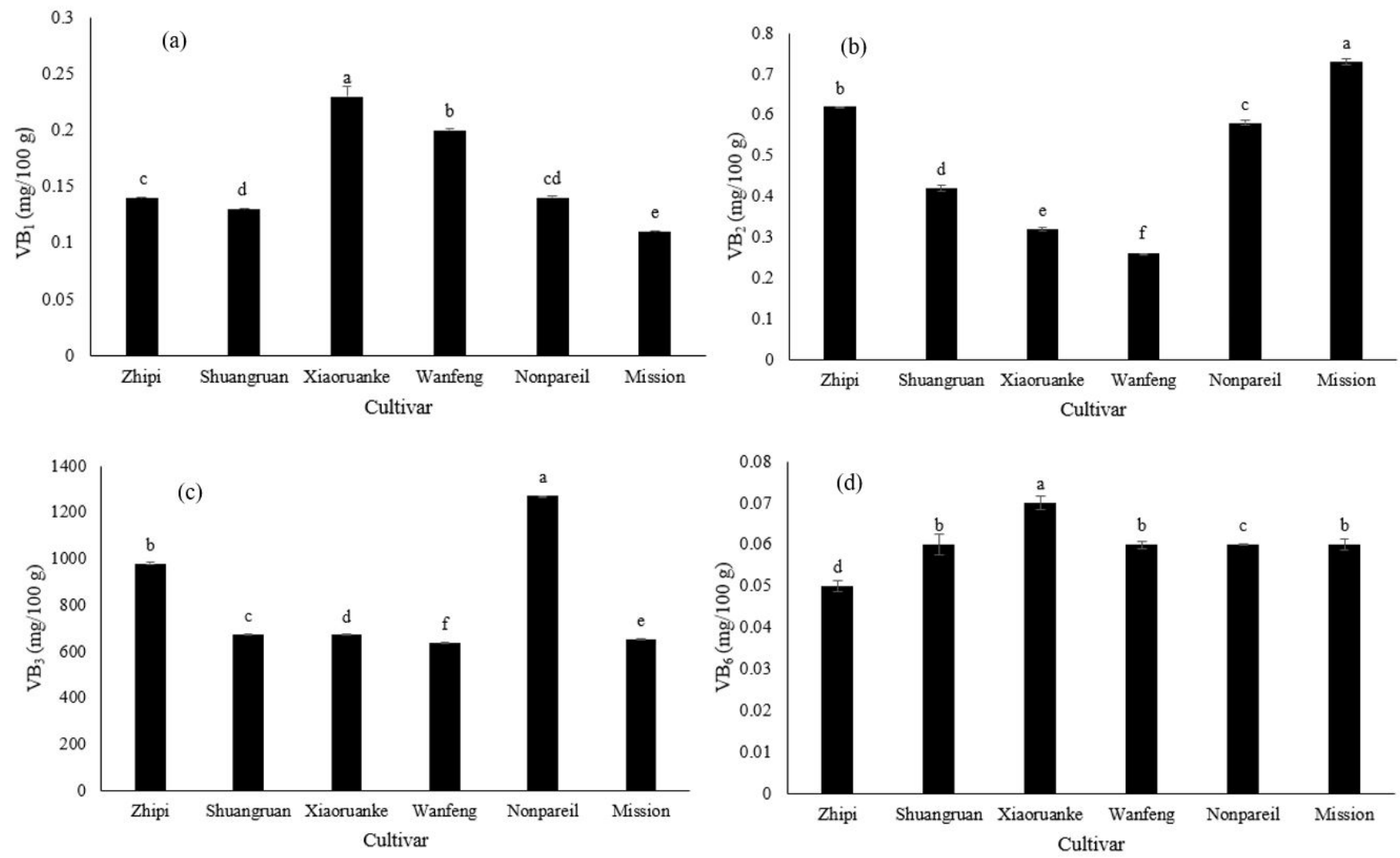

Figure 2. Vitamin $B_{1}(a), B_{2}(b), B_{3}(c)$, and $B_{6}(d)$ contents in kernels of six almond cultivars. Different lowercase letters above the columns indicate significant differences at the 0.05 confidence level according to ANOVA by Duncan's test. 


\subsection{Squalene and phospholipid contents}

Nowadays, the bioactivity of squalene is a hot topic. Squalene can regulate cholesterol metabolism, oxidisation, and radiation. It has oxygen carrying capacity (He \& Corke, 2003; Gunawan et al., 2008; Reddy \& Couvreur, 2009; Lou-Bonafonte et al., 2012). In the present study, the levels of squalene differed between almond cultivars, ranging from 131.20 to $274.80 \mathrm{mg} / \mathrm{kg}$ (Figure 3). Squalene content was the highest in 'Shuangruan', and it was 2.09 times higher than that of 'Nonpareil', which had the lowest squalene content.

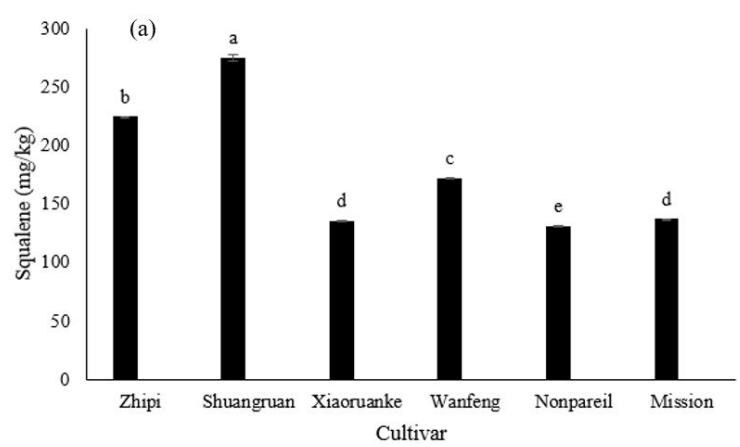

Phospholipids can promote fat metabolism, prevent fatty liver, reduce blood viscosity, and enhance haematopoietic function. They were detected in all cultivars, in levels ranging from 1.18 to $1.47 \mathrm{mg} / \mathrm{g}$. Phospholipid content was the highest in 'Zhipi' and the lowest in 'Xiaoruanke'.

\subsection{Principal component analysis}

Figure 4 shows the loading plot on the plane defined by the first and second principal components as well as the corresponding projection of samples. The variance contribution rate of the

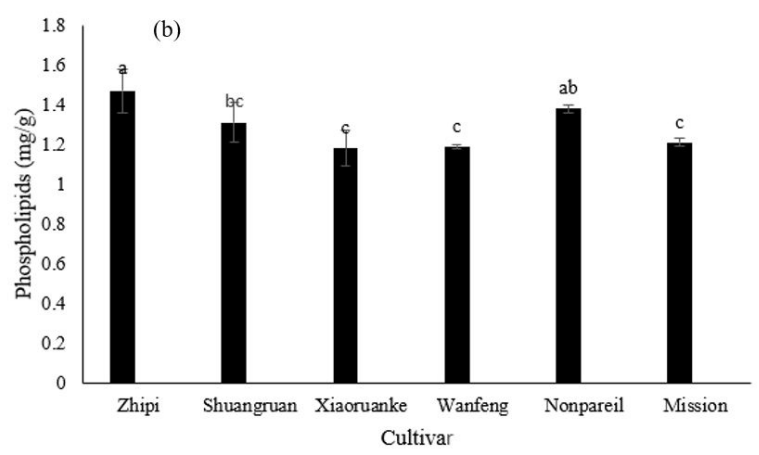

Figure 3. Squalene (a) and phospholipid (b) contents in kernels of six almond cultivars. Different lowercase letters above the columns indicate significant differences at the 0.05 confidence level according to ANOVA by Duncan's test.
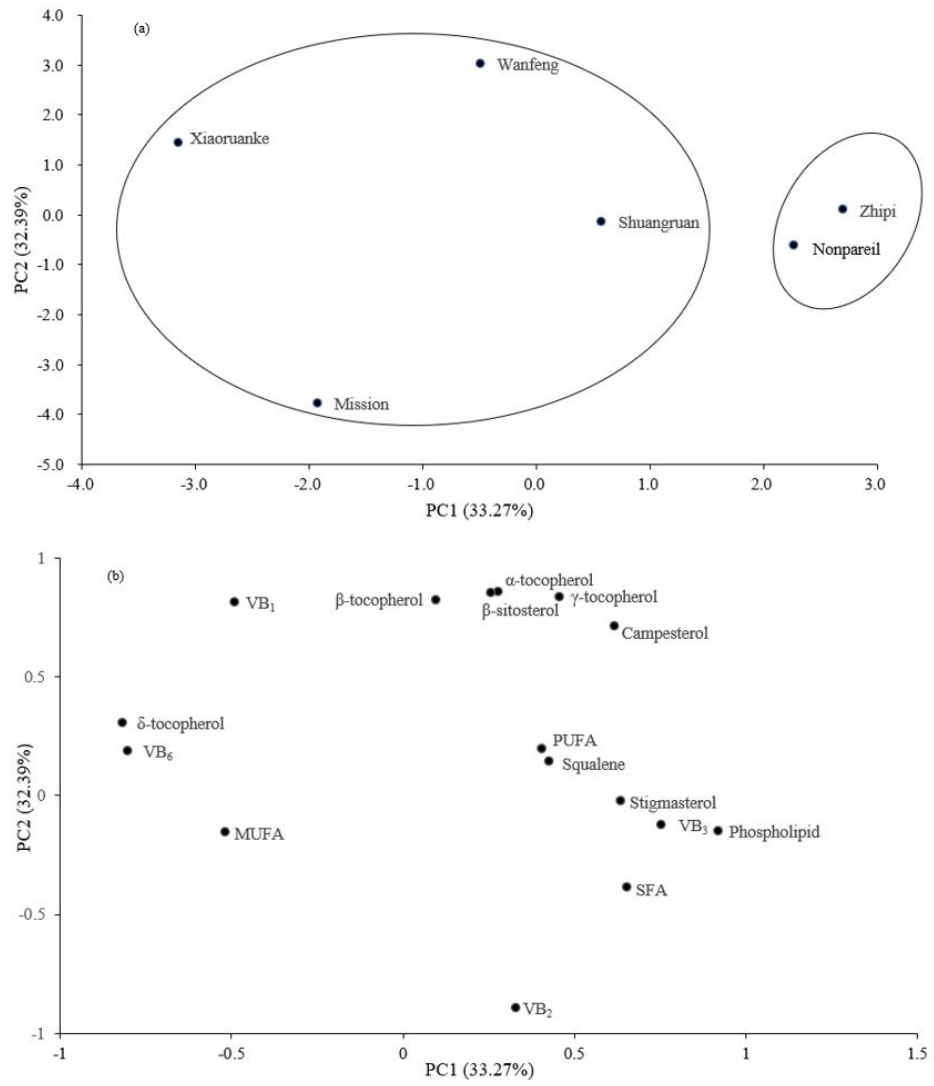

Figure 4. Representation of the six almond cultivars (a) and their measured oil chemical components, (b) defined by the first (PC1) and second principal component (PC2) obtained by Principal Component Analysis (PCA) ordination. "VB", "MUFA", "PUFA", and "SFA" represent "B vitamins", "monounsaturated fatty acids", "polyunsaturated fatty acids", and "saturated fatty acids", respectively. 
first principal component (PC1) and the second principal component (PC2) was $33.27 \%$ and $32.39 \%$, respectively. PC1 correlated highly with phospholipids, $\mathrm{VB}_{3}$, SFA, stigmasterol, and campesterol. PC2 correlated highly with $\alpha$-tocopherol, $\beta$-sitosterol, $\gamma$-tocopherol, $\beta$-tocopherol, $\mathrm{VB}_{1}$, and campesterol. The six almond cultivars could be divided into two groups based on the relationships between scores and their oil chemical traits. The first group consisted of 'Xiaoruanke', 'Mission,' 'Wanfeng', and 'Shuangruan', with a lower negative value of PC1. The second group was composed of 'Nonpariel' and 'Zhipi', with a higher positive value for PC1.

\section{Conclusions}

In the present study, we evaluated the oil chemical traits of kernels from six main almond cultivars in China, including four native and two traditional cultivars. The results indicated that there were some differences in the composition or content of fatty acids, tocopherols, sterols, $B$ vitamins $\left(B_{1}, B_{2}, B_{3}, B_{6}\right)$, squalene, and phospholipids among the six cultivars. UFAs were the most important contributors to fatty acids, containing significant amounts of MUFAs. Tocopherol levels were high, and $\alpha$-tocopherol was the predominant form of tocopherol. $\beta$-sitosterol was the most abundant phytosterol. The six cultivars were rich in squalene and had a wide range of B vitamin and phospholipid variability.

\section{Acknowledgements}

This study was supported by the Chinese Central Financial Forestry Science and Technology Promotion Demonstration Project (Xin [2018]TG17).

\section{References}

Abaspour, M., Imani, A., \& Hassanlo, T. (2012). Effects of almond genotype and growing location on oil percentage and fatty acid composition of its seeds. Journal of Nuts, 3(3), 5-12.

Al Juhaimi, F., Özcan, M. M., Ghafoor, K., Babiker, E. E., \& Hussain, S. (2018). Comparison of cold-pressing and soxhlet extraction systems for bioactive compounds, antioxidant properties, polyphenols, fatty acids and tocopherols in eight nut oils. Journal of Food Science and Technology, 55(8), 3163-3173. http://dx.doi.org/10.1007/s13197018-3244-5. PMid:30065427.

Amaral, J. S., Casal, S., Pereira, J. A., Seabra, R. M., \& Oliveira, B. P. (2003). Determination of sterol and fatty acid compositions, oxidative stability, and nutritional value of six walnut (Juglans regia L.) cultivars grown in Portugal. Journal of Agricultural and Food Chemistry, 51(26), 7698-7702. http://dx.doi.org/10.1021/jf030451d. PMid:14664531.

Bolling, B. W., Dolnikowski, G., Blumberg, J. B., \& Chen, C. O. (2010). Polyphenol content and antioxidant activity of California almonds depend on cultivar and harvest year. Food Chemistry, 122(3), 819-825. http://dx.doi.org/10.1016/j.foodchem.2010.03.068. PMid:25544797.

Cassady, B. A., Hollis, J. H., Fulford, A. D., Considine, R. V., \& Mattes, R. D. (2009). Mastication of almonds: effects of lipid bioaccessibility, appetite, and hormone response. The American Journal of Clinical Nutrition, 89(3), 794-800. http://dx.doi.org/10.3945/ajcn.2008.26669. PMid:19144727.

Clase, C. M., Ki, V., \& Holden, R. M. (2013). Water-soluble vitamins in people with low glomerular filtration rate or on dialysis: A review.
Seminars in Dialysis, 26(5), 546-567. http://dx.doi.org/10.1111/ sdi.12099. PMid:23859229.

Čolić, S. D., Fotirić Akšić, M. M., Lazarević, K. B., Zec, G. N., Gašić, U. M., Dabić Zagorac, D., \& Natić, M. M. (2017). Fatty acid and phenolic profiles of almond grown in Serbia. Food Chemistry, 234, 455-463. http://dx.doi.org/10.1016/j.foodchem.2017.05.006. PMid:28551260.

Derewiaka, D., \& Obiedziński, M. (2012). Phytosterol oxides content in selected thermally processed products. European Food Research and Technology, 234(4), 703-712. http://dx.doi.org/10.1007/s00217012-1681-3.

Fitzpatrick, T. B., \& Thore, S. (2014). Complex behavior: from cannibalism to suicide in the vitamin $\mathrm{B}_{1}$ biosynthesis world. Current Opinion in Structural Biology, 29, 34-43. http://dx.doi.org/10.1016/j. sbi.2014.08.014. PMid:25260119.

Gunawan, S., Kasim, N. S., \& Ju, Y. H. (2008). Separation and purification of squalene from soybean oil deodorizer distillate. Separation and Purification Technology, 60(2), 128-135. http://dx.doi.org/10.1016/j. seppur.2007.08.001.

Hälvin, K., Nisamedtinov, I., \& Paalme, T. (2014). Comparison of different extraction methods to determine free and bound forms of B-group vitamins in quinoa. Analytical and Bioanalytical Chemistry, 406(28), 7355-7366. http://dx.doi.org/10.1007/s00216-014-8122-z. PMid:25195054.

He, H. P., \& Corke, H. (2003). Oil and squalene in amaranthus grain and leaf. Journal of Agricultural and Food Chemistry, 51(27), 7913-7920. http://dx.doi.org/10.1021/jf030489q. PMid:14690373.

Hu, Y., Wu, H., Yin, X. L., Gu, H. W., Xiao, R., Xie, L. X., Liu, Z., Fang, H., Wang, L., \& Yu, R. Q. (2018). Rapid and interference-free analysis of nine B-group vitamins in energy drinks using trilinear component modeling of liquid chromatography-mass spectrometry data. Talanta, 180, 108-119. http://dx.doi.org/10.1016/j.talanta.2017.12.036. PMid:29332787.

Jiang, T., Lu, H., Wang, Y., Yu, W. W., Wu, L., \& Chen, H. M. (2015). The domestic and foreign research progress of determination of phospholipids. Shipin Yu Fajiao Gongye, 41, 259-264.

Köksal, A., Artik, N., Şimşek, A., \& Güneş, N. (2006). Nutrient composition of hazelnut (Corylus avellana L.) varieties cultivated in Turkey. Food Chemistry, 99(3), 509-515. http://dx.doi.org/10.1016/j. foodchem.2005.08.013.

Lehtonen, M., Lampi, A., Riuttamäki, M., \& Piironen, V. (2012). Oxidation reactions of steryl esters in a saturated lipid matrix. Food Chemistry, 134(4), 2030-2039. http://dx.doi.org/10.1016/j. foodchem.2012.04.007. PMid:23442653.

Li, Y., Yi, X. H., \& Li, Q. D. (2004). Nutritional evaluation of higher fatty acid and amino acid in 28 almond varieties from Xinjiang. Journal of Chinese Institute of Food Science and Technology, 4, 64-70.

López-Ortiz, C. M., Prats-Moya, S., Beltrán Sanahuja, A., \& MaestrePérez, S. E., Grané-Teruel, N., \& Martín-Carratalá, M. L. (2008). Comparative study of tocopherol homologue content in four almond oil cultivars during two consecutive years. Journal of Food Composition and Analysis, 21, 144-151.

Lou-Bonafonte, J. M., Arnal, C., Navarro, M. A., \& Osada, J. (2012). Efficacy of bioactive compounds from extra virgin olive oil to modulate atherosclerosis development. Molecular Nutrition \& Food Research, 56(7), 1043-1057. http://dx.doi.org/10.1002/mnfr.201100668. PMid:22760979.

Maestri, D., Martínez, M., Bodoira, R., Rossi, Y., Oviedo, A., Pierantozzi, P., \& Torres, M. (2015). Variability in almond oil chemical traits from traditional cultivars and native genetic resources from 
Argentina. Food Chemistry, 170, 55-61. http://dx.doi.org/10.1016/j. foodchem.2014.08.073. PMid:25306317.

Maguire, L. S., O’Sullivan, S. M., Galvin, K., O’Connor, T. P., \& O’Brien, N. M. (2004). Fatty acid profile, tocopherol, squalene and phytosterol content of walnuts, almonds, peanuts, hazelnuts and the macadamia nut. International Journal of Food Sciences and Nutrition, 55(3), 171-178. http://dx.doi.org/10.1080/09637480410 001725175 . PMid:15223592.

Ostrowska-Ligeza, E., Bekas, W., Kowalska, D., Lobacz, M., Wroniak, M., \& Kowalski, B. (2010). Kinetics of commercial olive oil oxidation: dynamic differential scanning calorimetry and Rancimat studies. European Journal of Lipid Science and Technology, 112(2), 268-274. http://dx.doi.org/10.1002/ejlt.200900064.

Reddy, L. H., \& Couvreur, P. (2009). Squalene: A natural triterpene for use in disease management and therapy. Advanced Drug Delivery Reviews, 61(15), 1412-1426. http://dx.doi.org/10.1016/j. addr.2009.09.005. PMid:19804806.

Sathe, S. K., Seeram, N. P., Kshirsagar, H. H., Heber, D., \& Lapsley, K. A. (2008). Fatty acid composition of California grown almonds. Journal of Food Science, 73(9), C607-C614. http://dx.doi.org/10.1111/j.17503841.2008.00936.x. PMid:19021789.

Schwechheimer, S. K., Park, E. Y., Revuelta, J. L., Becker, J., \& Wittmann, C. (2016). Biotechnology of riboflavin. Applied Microbiology and Biotechnology, 100(5), 2107-2119. http://dx.doi.org/10.1007/s00253015-7256-Z. PMid:26758294.

Settembre, E., Begley, T. P., \& Ealick, S. E. (2003). Structural biology of enzymes of the thiamin biosynthesis pathway. Current Opinion in Structural Biology, 13(6), 739-747. http://dx.doi.org/10.1016/j. sbi.2003.10.006. PMid:14675553.
Socias i Company, R., Ansón, J. M. \& Espiau, M. T. (2017). Taxonomy, botany and physiology. In R. Sociais I Company \& T. M. Gradziel (Eds.), Almonds: Botany, Production and Uses. Boston: CABI.

Sorkheh, K., Kiani, S., \& Sofo, A. (2016). Wild almond (Prunus scoparia L.) as potential oilseed resource for the future: Studies on the variability of its oil content and composition. Food Chemistry, 212, 58-64. http://dx.doi.org/10.1016/j.foodchem.2016.05.160. PMid:27374506.

Vanmierlo, T., Husche, C., Schött, H. F., Pettersson, H., \& Lütjohann, D. (2013). Plant sterol oxidation products-Analogs to cholesterol oxidation products from plant origin. Biochimie, 95(3), 464-472. http://dx.doi.org/10.1016/j.biochi.2012.09.021. PMid:23009926.

Wang, W., Wang, H. L., Xiao, X. Z., \& Xu, X. Q. (2019). Wild almond (Amygdalus pedunculata Pall.) as potential nutritional resource for the future: studies on its chemical composition and nutritional value. Journal of Food Measurement and Characterization, 13(1), 250-258. http://dx.doi.org/10.1007/s11694-018-9939-5.

Yin, J. Y., Zhang, Q., Tian, J., Li, P., \& Li, J. (2015). Analysis of nut qualities of almond varieties in Xinjiang. Nonwood Forest Research, 33(4), 58-64.

Zhou, Q., Zhang, H. N., Huang, F. H., Li, S. G., Yang, M., \& Zheng, C. (2016). Characteristics of cold-pressed almond oil from different cultivars in Xinjiang region. Zhongguo Youliao Zuowu Xuebao, 38(5), 672-680.

Zhu, Y., Taylor, C., Sommer, K., Wilkinson, K., \& Wirthensohn, M. (2015). Influence of deficit irrigation strategies on fatty acid and tocopherol concentration of almond (Prunus dulcis). Food Chemistry, 173, 821-826. http://dx.doi.org/10.1016/j.foodchem.2014.10.108. PMid:25466095. 